\title{
Coronary Artery Calcium Scanning and Conflicts of Interest
}

\section{Citation}

Cohen, Pieter A. 2012. "Coronary Artery Calcium Scanning and Conflicts of Interest." Archives of Internal Medicine 172 (8) (April 23). doi:10.1001/archinternmed.2012.276.

\section{Published Version}

10.1001/archinternmed.2012.276

\section{Permanent link}

http://nrs.harvard.edu/urn-3:HUL.InstRepos:34902784

\section{Terms of Use}

This article was downloaded from Harvard University's DASH repository, and is made available under the terms and conditions applicable to Other Posted Material, as set forth at http:// nrs.harvard.edu/urn-3:HUL.InstRepos:dash.current.terms-of-use\#LAA

\section{Share Your Story}

The Harvard community has made this article openly available.

Please share how this access benefits you. Submit a story.

Accessibility 
kins Bloomberg School of Public Health (Drs Pollack and Bhavsar), and Johns Hopkins Community Physicians (Drs Noronha and Green), Baltimore, Maryland.

Correspondence: Dr Pollack, Division of General Internal Medicine, Johns Hopkins University School of Medicine, 2024 E Monument St, Room 2-615, Baltimore, MD 21287 (cpollac2@jhmi.edu).

Author Contributions: Study concept and design: Pollack, Noronha, Green, Bhavsar, and Carter. Acquisition of data: Pollack, Noronha, and Green. Analysis and interpretation of data: Pollack. Drafting of the manuscript: Pollack. Critical revision of the manuscript for important intellectual content: Pollack, Noronha, Green, Bhavsar, and Carter. Statistical analysis: Pollack. Obtained funding: Pollack and Carter. Administrative, technical, and material support: Pollack, Noronha, and Green. Study supervision: Noronha, Green, and Carter.

Financial Disclosure: Dr Pollack's salary was supported by a career development award from the National Cancer Institute and the Office of Behavioral and Social Sciences Research, National Institutes of Health (1K07CA15191001A1). Dr Bhavsar's salary was supported by Agency for Healthcare Research and Quality grant T32HS019488. Ms Murphy received financial compensation from the Maryland Cigarette Restitution Fund.

Funding/Support: This study was supported in part by a Maryland Cigarette Restitution Fund Research Grant to the Johns Hopkins Institutions.

Role of the Sponsor: The Maryland Cigarette Restitution Fund had no role in the design and conduct of the study; in the collection, analysis, and interpretation of the data; or in the preparation, review, or approval of the manuscript.

Additional Contributions: Elizabeth A. Platz ScD, MPH, contributed to the study design, survey development, data interpretation, and manuscript revision, and Erin Murphy and Sean Chen assisted with the survey.

1. Screening for prostate cancer: draft recommendation statement AHRQ publication No. 12-05160-EF-2. US Preventive Services Task Force Web site. http: //www.uspreventiveservicestaskforce.org/uspstf12/prostate/draftrec3.htm. Accessed December 7, 2011.

2. Wolf AM, Wender RC, Etzioni RB, et al; American Cancer Society Prostate Cancer Advisory Committee. American Cancer Society guideline for the early detection of prostate cancer: update 2010. CA Cancer J Clin. 2010;60(2):70-98.

3. Greene KL, Albertsen PC, Babaian RJ, et al. Prostate specific antigen best practice statement: 2009 update. J Urol. 2009;182(5):2232-2241.

4. Linder SK, Hawley ST, Cooper CP, Scholl LE, Jibaja-Weiss M, Volk RJ. Primary care physicians' reported use of pre-screening discussions for prostate cancer screening: a cross-sectional survey. BMC Fam Pract. 2009;10:19. doi:10.1186/1471=2296-10-19.

5. Drazer MW, Huo D, Schonberg MA, Razmaria A, Eggener SE. Populationbased patterns and predictors of prostate-specific antigen screening among older men in the United States. J Clin Oncol. 2011;29(13):1736-1743.

\section{COMMENTS AND OPINIONS}

\section{Coronary Artery Calcium Scanning and Conflicts of Interest}

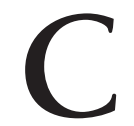

oronary artery calcium (CAC) score and high-sensitivity C-reactive protein level are currently the leading contenders to join traditional risk factors in routine clinical assessment of coronary heart disease risk. I do not believe that there is sufficient data to use either at present, and I read with interest the thoughtful critique of CAC scanning by Ridker. ${ }^{1}$ No conflicts of interest are reported, but Ridker is a co-inventor on patents held by Brigham and Women's Hospital that use high-sensitivity C-reactive protein in assessing cardiovascular disease risk. Having a financial stake in a competitor of CAC scanning for coronary artery disease risk stratification is an important conflict of interest to share with readers.

\section{Pieter A. Cohen, MD}

Author Affiliation: Department of Medicine, Cambridge Health Alliance, Harvard Medical School, Cambridge, Massachusetts.

Correspondence: Dr Cohen, Department of Medicine, Cambridge Health Alliance, Harvard Medical School, 1493 Cambridge St, Cambridge, MA 02139 (Pieter_cohen @hms.harvard.edu).

Financial Disclosure: None reported.

1. Ridker PM. Coronary artery calcium scanning in primary prevention: a conversation with cardiology fellows. Arch Intern Med. 2011;171(22):2051-2052.

$$
\text { In reply }
$$

In my recent Commentary in the Archives on coronary artery calcium scanning, ${ }^{1}$ there is no disclosure of my conflict of interest with regard to inflammatory biomarkers and cardiovascular disease because the commentary contains no discussion of this topic. However, as requested by Dr Cohen, my disclosure is provided below.

Paul M. Ridker, MD

Author Affiliation: Center for Cardiovascular Disease and Prevention, Brigham and Women's Hospital, Boston, Massachusetts.

Correspondence: Dr Ridker, Center for Cardiovascular Disease and Prevention, Brigham and Women's Hospital, 900 Commonwealth Ave E, Boston, MA 02215 (pridker@partners.org).

Financial Disclosure: Dr Ridker is listed as a coinventor on patents held by the Brigham and Women's hospital that relate to the use of inflammatory biomarkers in cardiovascular disease and diabetes that have been licensed to AstraZeneca and Seimens.

1. Ridker PM. Coronary artery calcium scanning in primary prevention: a conversation with cardiology fellows. Arch Intern Med. 2011;171(22):2051-2052.

\section{Cardiac Implantable Electronic Devices: Prevention Starts From Ethics}

$\mathrm{W}$ e read with interest the article by Sohail et al, ${ }^{1}$ in which infections related to cardiovascular implantable electronic devices (CIEDs) were associated with substantial admission and long-term mortality. The importance of clinical and technical procedures for infection prevention was stressed in the "Comment" section and the related Commentary. ${ }^{2}$ However, an additional major issue 